\title{
Japan to merge science with education
}

[TOKYO] Plans to merge the Science and Technology Agency (STA) and the Ministry for Education, Science, Sports and Culture (Monbusho) into a new Ministry of Education, Science and Technology have been confirmed by Japan's administrative reform council, chaired by Prime Minister Ryutaro Hashimoto. This follows an interim proposal put forward by the council in August (see Nature 388, 815: 1997).

The decision emerged last week from a four-day meeting during which the reform council tried to finalize plans to cut the number of ministries and agencies from 22 to 13 .

In contrast to lobbying from bureaucrats against the restructuring of other ministries and agencies, the plan to merge the STA and Monbusho has faced relatively little opposition. The restructuring is planned to take effect from 2001 and legislation will be submitted to Japan's parliament next year.

Monbusho officials are backing the merger, which they consider "crucial" to increasing the number of individuals in basic research and technology as Japan's population falls. The merger with STA, Monbusho says, is a "perfect opportunity to place more emphasis on science in higher education".

But research bodies funded through both Monbusho and STA are less positive. Many view STA's 'top-down' approach and Monbusho's education-oriented approach as fundamentally incompatible, and heads of government research organizations are watching nervously as the plans consolidate.

Minoru Oda, former director general of the Institute of Space and Astronomical Science (ISAS) under Monbusho, who also headed the Institute of Physical and Chemical Science (RIKEN) under the STA, is concerned the merger could jeopardize support for basic research, whose importance Monbusho has only recently begun to appreciate. "There is very little support and understanding for basic research in Japan," he says. "Many people, including both scientists and bureaucrats, have often missed the point that 'science' and 'technology' are separate issues."

One of Oda's main concerns is that ISAS might be merged with the National Space Development Agency (NASDA) under STA. ISAS, which formerly belonged to Tokyo University, is a successful academic institute carrying out basic research in space science using small low-budget satellites and rockets. NASDA, in contrast, is devoted mainly to the launch of large applications satellites and is staffed mainly by engineers.

Oda fears that a merger under the revamped ministry might appeal to politicians and the public, whose main concern is reducing the burden of bureaucracy. "The foundation for basic science in Japan is still

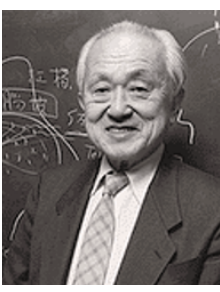

Oda: sees threat to basic research.

"might generate some potential benefits by breaking the bureaucratic wall between the two sides". But he adds the gap between their policies "may overshadow such benefits".

But supporters of the merger argue that it could give more flexibility to Monbusho's current funding system, which splits funds in a bureaucratic fashion criticized as rigid, inflexible and 'over-democratic'. Some propose converting national laboratories and semi-public institutes, such as RIKEN, to 'independent administrative agencies' to give them financial independence, as well as requiring greater accountability.

"The current funding system [under Monbusho] is unsuitable for basic research," says Keiichi Kodaira, head of the National Astronomical Observatory. "Turning research institutes into more autonomous 'agencies' might be worth considering, although this needs to be looked into more carefully," he adds.

The decision to merge STA and Monbusho was strongly promoted by Hashimoto, who was exasperated by the mishandling of nuclear accidents at STA's Power Reactor and Nuclear Fuel Corporation (PNC). He said in August he opposed an earlier proposal to upgrade STA into a ministry. STA officials say the agency probably would have become a full ministry of science but for the scandals surrounding PNC.

"With the creation of the basic law for science and technology last year, and an increase in budget for scientific research, STA's position was rapidly rising," says Fumio Saito, head of the administrative reform committee at the ruling Liberal Democratic Party. Saito lobbied against the merger. "Downgrading STA just because of what happened at PNC is frivolous," he says.

Part of the nuclear policy division within PNC, as well as other policy-making sections from STA, will now be incorporated into a strengthened Council of Science and Technology, Japan's leading science policy-making body within the Prime Minister's office.

The Environment Agency, which is to be upgraded into a 'ministry of environment safety', is to absorb the nuclear waste division of the ministry of health and welfare, as well as taking a stronger role in implementing policies on the emissions of greenhouse gases.

AsakoSaegusa

\section{Australia annuls Roche's native Taqpatent}

[LONDON] The legal tussle about rights to the thermostable enzyme Taq DNA polymerase has taken a new turn with a decision by the Australian Patent Office (APO) to withdraw patent rights to the enzyme in its native form issued to Swiss company HoffmannLa Roche.

The decision has been welcomed by officials at New England Biolabs (NEB), which had led a challenge - together with the company Bresatec (now Bresagen) - to Roche's Australian patent on Taq, used extensively in laboratories as part of the polymerase chain reaction technique.

But Roche, which is also facing a court challenge to the US Taq patent from the laboratory equipment company Promega, has shrugged off the Australian decision. It argues that it has further information to back up its patent application which it has yet to present to the courts. (The company's patents to recombinant Taq and related products were upheld.)

The decision by the APO examiner focused on 'prior art', and in particular on claims by NEB and Promega, both of which have been selling versions of Taq, that its existence had been known to other researchers before its claimed 'discovery' by the US company Cetus in the mid-1980s.

The examiner supported, for example, the claim that a thermostable enzyme extracted by Russian scientists in the 1970s was essentially identical to that described in the patent application. The rejection of this argument by the European Patent Office last year was largely responsible for Roche being awarded the European patent on all forms of Taq (see Nature 384, 100; 1996)

Donald G. Comb, president of NEB, claimed last week that the APO decision "affirms the view of many scientists in the world that this and similar patents to native Taq DNA polymerase should never have been issued". Officials from Promega express the hope that "the US court, as well as the EPO in upcoming opposition proceedings, will follow Australia's lead".

But Roche said on Monday (24 November) that it had "for formal reasons" not been able to present to the APO the "strong evidence" it had provided to the EPO refuting opponents' claims of 'prior art'. Roche says it is "confident" that it will win an appeal it has now lodged with the Federal Court in Sydney.

David Dickson 